\title{
The French Communist Party and Britain in the Second World War
}

\author{
Gavin Bowd
}

The French Communist Party (PCF) is not normally associated with Britain:

commentators have preferred to concentrate on its relationship with the Soviet Union, its role in the anti-colonial struggle, and its hostility to Americanisation and European unification. The PCF is compared far more often with the Italian Communist Party, than with its poor neighbour across the Channel, the Communist Party of Great Britain (CPGB). ${ }^{1}$ However, in the course of the Second World War, the PCF's relationship with Britain illustrates the tortuous trajectory of the Communist movement and offers insights into its role in the French Resistance, with all the changes of alliance and re-writing of recent history that this entailed. Documents and publications of the PCF and CPGB help to trace transnational exchanges that were ultimately determined by dramatic shifts in geopolitics.

\section{Against Perfidious Plutocracy}

At first, the signature of the Nazi-Soviet non-aggression pact, then the Franco-British declaration of war, did not tear apart the Communist movement. Although L'Humanité and Ce Soir were banned on 26 August 1939, the Communist deputies still approved money for the war effort on 2 September. It was believed that the pact with Hitler was a tactical move to defend the homeland of Bolshevism: war against

\footnotetext{
${ }^{1}$ See Stéphane Courtois and Marc Lazar, Histoire du Parti communiste français (Paris: PUF, 1995), and Marc Lazar, Maisons rouges. Les Partis communistes français et italien de la Libération à nos jours (Paris: Aubier, 1992).
} 
Nazism would continue in the West. However, on 7 September, Joseph Stalin made clear to the Comintern that the Allies' 'imperialist war' had to be opposed at all costs. What is more, on 26 September, a pact of friendship placed Nazi Germany firmly in the 'peace' camp. During the weeks that followed, the invasion of the Baltic States illustrated the carving up of Eastern Europe which had been secretly agreed by Molotov and Von Ribbentrop.

On 26 September, the PCF was dissolved. Its Comintern mentor, Eugen Fried, moved to Brussels to direct operations in Western Europe, and was joined by French leaders Jacques Duclos and Maurice Tréand. In France, the remaining leadership was dislocated, its membership drained by mobilisation and mass disenchantment. The Party which had made a major breakthrough in 1936 was rapidly reduced to a few thousand members. On 1 October, Jacques Duclos demanded that France open peace negotiations with Hitler: this request was met with increased repression and arrests of Communist deputies, councillors and trade unionists. On 4 October, with the help of a Party commando, Maurice Thorez deserted from the army and made for Brussels, from where he would continue to Moscow. Communist 'treachery' seemed confirmed in the eyes of the French authorities. As for the CPGB, the new 'anti-imperialist' line, which made Britain and France ultimately responsible for the conflict, led to the replacement of its general secretary, Harry Pollitt, by the ultra-orthodox R. Palme Dutt.

On 26 October, L'Humanité re-appeared illegally. The changes of the last two months were manifest, with words like nazi and hitlérien disappearing from its vocabulary. Instead, on 30 October 1939, the Party newspaper declared itself 'contre la guerre des capitalistes. Pour détruire la puissance des oligarchies, qui en sont 
responsables'. ${ }^{2}$ In this issue, Thorez's remarks on Britain were in the new antiimperialist line, presenting perfidious Albion as the enemy of France. Every time capitalist France had tried to profit from her victory in 1918, Britain had been there to do a deal with Germany. This selfish and destructive foreign policy had continued with Britain's hostility to the Spanish Republic. Now appeasement had given way to aggression. Thorez concluded:

Nous aimons le peuple anglais que nous ne confondons pas avec le gouvernement conservateur d'Angleterre, comme je le disais au banquet de la presse anglo-américaine en mai 1936. Nous aimons tous les peuples, nous ne confondons pas le peuple allemand avec ses maîtres du moment et nous agissons en défense du peuple français en ne voulant pas que la jeunesse de notre pays soit jetée en holocauste aux capitalistes anglais en lutte d'intérêts avec les capitalistes allemands. Nous souffrons de voir qu'un Daladier peut froidement sacrifier des vies françaises à des intérêts qui ne sont pas ceux du peuple de France. ${ }^{3}$

At the beginning of November, Sam Russell, Paris correspondent of the Daily Worker, himself seeking refuge in Brussels, was offered a journalistic scoop: an interview with the deserter Thorez. In 1991, Russell recounted his secret rendez-vous with le fils du peuple:

Il fait déjà noir et il tombe une pluie battante. Je suis à côté de Tréand qui ne dit rien et nous roulons une heure jusqu'à un endroit que je n'ai jamais pu

\footnotetext{
${ }^{2}$ L'Humanité clandestine, ed. by Germaine Willard, 2 vols (Paris: Messidor, 1975), I, 55.

${ }^{3}$ L'Humanité clandestine, I , 51-53.
} 
identifier, à l'extérieur de Bruxelles, en tout cas, probablement aux alentours d'une grande ville [Bruges]. On s'arrête finalement devant une maison: c'est là ! Nous entrons, je m'assois et je patiente quelques minutes. Thorez descend les marches de l'escalier, me salue, décontracté, presque guilleret, me dit qu'il a préparé des réponses, qu'il est prêt à me consacrer un moment autour d'un café, si j'ai d'autres questions. Je lis mon texte, qui est déjà dactylographié; nous discutons, je prends pas mal de notes et, après une heure et demie, nous nous quittons. ${ }^{4}$

The interview was published on the front page of the Daily Worker on 4 November, under the headline, 'Outlawed French leader tells why he is hunted'. It caused consternation in France, leading the far right deputy, Pierre Taittinger, to tell the Chamber: 'A quoi bon interdire L'Humanité si la presse communiste anglaise est autorisée en France!.'5

Extracts of the interview were reproduced in the seventh clandestine issue of L'Humanité, on 17 November (three days after Thorez gave a report on the French situation to the Comintern Executive Committee in Moscow). The paper was proud to cite Russell's remark that 'jamais je ne vis Thorez plus confiant en son Parti, dans ses camarades et dans l'avenir du Peuple Français'. The General Secretary informed his readers that the forces of reaction in France, including Daladier and the Parti socialiste, were infuriated by the PCF's denunciation of the Allies' true war aim: 'la destruction de la mère-patrie du socialisme, l'Union soviétique'. Thorez pledged to

\footnotetext{
${ }^{4}$ Guillaume Bourgeois, 'Entretien avec Sam Russell', Communisme, 87, (2006), 11-19.

${ }^{5}$ Bourgeois, 'Entretien avec Sam Russell', 17.
} 
continue the struggle, asserting that he had deserted in order to 'rester à [s]on poste dans la guerre des classes' ${ }^{6}$

These attacks on an inter-imperialist war were echoed in the Daily Worker. In December, after a meeting in Paris between the moderate TUC leader Walter Citrine and the French labour minister Charles Pomaret, the Communist daily accused Citrine of plotting to drag millions of Anglo-French trade unionists behind the Anglo-French imperialist war machine. Citrine reacted by successfully suing for libel. But the PCF adopted a more national-cum-chauvinist rhetoric to fit the Comintern line. During the drôle de guerre, the PCF attempted to gain support among French soldiers and their families by claiming they were paid and fed much less than their so-called allies from across the Channel. On 28 January 1940, L'Humanité contrasted 'menu anglais et rata français': 'La nourriture des troupes anglaises comporte hors-d'œuvre, jambon, viande et légumes, fruits, mais le soldat français doit se contenter d'un rata à peine plus varié que celui qu'on sert dans les prisons" ${ }^{\text {"7 }}$ On 1 May 1940, just before the invasion of France, L'Humanité du Soldat continued to stoke up resentment against the British, in this case visiting female volunteers:

De riches Anglaises insultent nos malheurs par leurs parades en uniforme. Leurs indécentes coquetteries mettent en évidence la soumission de la France envers les ploutocrates britanniques. Asservis économiquement, militairement et politiquement, notre pays est transformé en 'dominion' anglaise. ${ }^{8}$

\footnotetext{
${ }^{6}$ L'Humanité clandestine, I , 67-68.

${ }^{7}$ L'Humanité clandestine, I, 118.

${ }^{8}$ Archives du Parti Communiste Français (Bobigny): 3 MI 6/140 [emphasis in original] (hereafter APCF).
} 
Communist vitriol did not spare their erstwhile allies in the Front Populaire. In February 1940, under the title 'Syntaxe', L'Humanité instructed its readers: 'Ne dites pas "le citoyen BLUM" mais dites: "le City-oyen BLUM"..9 On 17 June 1940, as Pétain declared that 'il faut cesser le combat', L'Humanité asked: 'Est-ce que la Cité de Londres obtiendra la continuation du massacre de nos frères et de nos fils, pour permettre à l'Angleterre impérialiste, avec ses 40 millions d'habitants, d'en exploiter 400 millions [in an expanded Empire]?.'10

In the course of June, Jacques Duclos and Maurice Tréand followed the Wehrmacht into Paris in a Soviet diplomatic car. On arrival, the leadership called for fraternisation with German troops and put out feelers to the German ambassador, Otto Abetz, with a view to legalisation of the Party and its press. Indeed, the PCF denounced the call for resistance emanating from London. On 1 July 1940, the front page headline of L'Humanité was 'PAS POUR L'ANGLETERRE'11. Three days later, the paper claimed that the French people 'demande d'énergiques mesures contre tous ceux qui, par ordre de l'Angleterre, impérialiste, voudraient entraîner à nouveau les Français dans la guerre. Il demande la conclusion d'un pacte d'amitié francosoviétique qui complèterait le pacte germano-soviétique et serait la garantie de la paix en Europe. Il demande la conclusion d'un accord commercial avec l'URSS en vue d'aider notre pays à surmonter ses difficultés de ravitaillement ${ }^{12}$. On 6 July, a virulently anti-British issue of Ce Soir had been prepared in anticipation of approval by the Propagandastaffel.

However, the attempts at finding an agreement with the Occupier dismayed Party leaders in the provinces and even in Moscow: it was believed, rightly, that such

\footnotetext{
${ }^{9}$ L'Humanité clandestine, I, 120.

${ }^{10}$ L'Humanité clandestine, I, 169-70.

${ }^{11}$ L'Humanité clandestine, I, 192.

${ }^{12}$ L'Humanité clandestine, I, 196.
} 
a rapprochement would compromise the Party and leave it wide open to police repression. On 17 July, at the behest of Thorez, Moscow telegraphed new directives to Paris:

Etait juste entreprendre démarches pour obtenir presse légale, mais entrevue avec Abetz faute, car danger compromettre Parti et militants (...) Préférable garder silence sur de Gaulle et ne pas mettre accent contre Angleterre afin de ne pas faciliter politique Pétain et ses protecteurs. Juste proposer entente avec l'URSS mais sans la présenter comme un complément pacte germanosoviétique et sans parler de pacification Europe. ${ }^{13}$

However, the Party remained resolutely pacifist. In January 1941, L'Humanité continued to attack both sides in the conflict:

Les premiers veulent se servir de l'Afrique du Nord comme base d'opération contre l'Angleterre et les seconds veulent se servir de cette même Afrique du Nord pour pousser leurs avantages contre l'Italie et partant contre les puissances de l'Axe. De toutes façons, les deux solutions que les impérialistes offrent à la France, c'est la guerre, la guerre sous le signe de la collaboration ou la guerre sous le signe d'une prétendue résistance à l'oppresseur. ${ }^{14}$

The anti-British, even chauvinist, declarations of the PCF during this period were not reciprocated by the CPGB. However, as demonstrated in Ivor Montagu's book, The

\footnotetext{
${ }^{13}$ Courtois and Lazar, Histoire du Parti communiste français, 175.

${ }^{14}$ L'Humanité clandestine, I, 331 [emphasis in the original].
} 
Traitor Class, published after the fall of France, ${ }^{15} \mathrm{CPGB}$ and PCF were joined in denouncing a plutocratic 'Fifth Column' that was all too ready to sell out 'the People'. In language reminiscent of 'Third Period' sectarianism, ${ }^{16}$ the alleged complicity of the social-democratic frère-ennemi was singled out for attack. For the Daily Worker, 'Léon Blum and the French Socialist Party participated in the attacks upon the CP which preceded its suppression' ${ }^{17}$ The Socialists, like Labour, were involved in 'intensifying' war, trying to spread it to neutral states in Eastern Europe and Scandinavia, while inflicting repression and misery at home. In May 1940, when Léon Blum addressed the Bournemouth conference of the Labour Party, the Daily Worker offered this 'potted history': 'Member of the big banking family of Maison Blum. Intimate friend of France's leading reactionaries. Profession, lawyer, who has continually defended the interest of the 200 banking and industrial families in the courts. Violent enemy of the Soviet Union'. ${ }^{18}$ This was accompanied by details of new repressive measures imposed on French workers. When France fell, the Daily Worker drew the lessons of this debacle: 'The same kind of leaders who brought France to defeat are in high places in Britain. They have the same record, policy and aims, as those who are responsible for Hitler's victory over France'. ${ }^{19}$ It was time to clear out the 'men of Munich' and create a 'new government' for the workers.

The French Communists, like their British counterparts, therefore concentrated on the class struggle: economic demands rather than war against the Axis. Industrial unrest across the Channel was followed with interest by the French leadership. In a report of 13 January 1941, 'Simon' wrote:

\footnotetext{
${ }^{15}$ Ivor Montagu, The Traitor Class (London: Lawrence and Wishart, 1940).

${ }^{16}$ Between 1927 and 1934, the Comintern adopted a policy of 'class against class', according to which the enemy was social-democratic 'reformism', considered 'fascist' and the last rampart of a doomed capitalist system.

${ }^{17}$ Daily Worker, 28 September 1939, 2.

${ }^{18}$ Daily Worker, 16 May 1940, 3.
} 
A propos de revendications ouvrières, vous savez que les mécaniciens ont introduit une demande d'augmentation de salaires contre les dirigeants des Trades-Unions. De plus le journal du parti communiste anglais est poursuivi par Citrine pour avoir révélé qu'au cours de la dernière réunion syndicale franco-anglaise, Jouhaux [Socialist leader of the CGT] demanda aux Anglais de faire en sorte qu'il n'y ait pas d'augmentation de salaires en Angleterre sans quoi il ne se sentait pas en mesure d'empêcher en France le dépôt de revendications analogues; c'est pourquoi il faudrait suivre de près ce qui se passe dans les usines. ${ }^{20}$

In that month, L'Humanité saluted those Anglo-Saxon workers fighting 'les ploutocrates de tous les pays': 'BRAVO, CAMARADES GREVISTES. Il y a des grèves en Amérique et en Angleterre. Les ouvriers de ces pays défendent leurs droits de travailleurs. La sympathie des ouvriers français leur est acquise' ${ }^{21}$

\section{Anti-Fascism Regained}

Since late 1940, there had been signs that the PCF was returning to the anti-Fascist struggle. On 11 November 1940, Communist students had joined a patriotic march to the Arc de Triomphe. By the beginning of 1941, the term nazi had reappeared in party literature, and in May-June, under the leadership of Auguste Lecœur, the coalfields of the Nord were paralysed by a general strike which rapidly took on an anti-German tone in an area with painful memories of the occupation of 1914-18. The increasing

\footnotetext{
${ }^{19}$ Daily Worker, 22 June 1940, 4.

${ }^{20}$ APCF: 3 MI 6/139.
} 
discontent at treatment by the Occupier, plus the deteriorating relations between Moscow and Berlin, encouraged a change in the line of the Muscovite leadership. On 22 June, Hitler's invasion of the Soviet Union brutally clarified the Communist position and dispelled the doubts of many anti-Fascists. The party threw itself into the armed struggle against the Occupier and its collaborators, triggering a cycle of armed attacks and reprisals - notably the execution of 48 hostages, including the young Communist Guy Môquet, at Châteaubriant in October 1941 — which would eventually make of the PCF the self-styled parti des fusillés.

On 17 July 1941, L'Humanité hailed agreement between Stalin and Churchill. On 11 September, the paper praised a man previously denounced as a reformist enemy of the workers:

Au récent congrès des Trade-Unions britanniques, Walter Citrine a proposé la création d'un comité syndical anglo-soviétique. C'est avec joie que les travailleurs de tous les pays saluent la constitution de ce comité qui coordonnera les efforts des travailleurs anglais et soviétiques dans la lutte à mort qui est livrée au fascisme allemand, ennemi de la civilisation. ${ }^{22}$

In October, the paper denounced the Munich Agreement, but passed over the NaziSoviet Pact, and praised a new Resistance:

Ce qu'il faut, c'est l'union et l'action du peuple français aux côtés des autres peuples asservis, aux côtés des Anglais, aux côtés des troupes de De Gaulle, et

${ }^{21}$ L'Humanité clandestine, I, 322.

${ }^{22}$ L'Humanité clandestine, I, 469-70. 
aux côtés des héroïques soldats de l'Armée Rouge. L’heure de la revanche des peuples approche à grands pas. ${ }^{23}$

The British people therefore took their place in the holy alliance against Fascism. At this time, the Daily Worker League produced a pamphlet in French in homage to Gabriel Péri, Communist deputy and international editor of L'Humanité, shot by the Nazis on 15 December 1941. William Rust, last editor of the still-suppressed British Communist daily, saw in Péri's martyrdom inspiration for struggles both at home and abroad: 'Nous admirons l'homme, le leader, le journaliste. Il n'appartient pas à la France seule, mais aux peuples de tous les pays. Sachons, et surtout ceux qui luttent contre la suppression injuste du Daily Worker, prendre exemple de la vie de Gabriel Péri. ${ }^{24}$

In May 1942, L'Humanité attempted to appropriate Jeanne d'Arc, heroine of the Pétainist Révolution nationale. She was instead portrayed as a precursor of the Resistance. The Bishop Cauchon, who had her burned at the stake at the behest of the occupier, anticipated the collaborators of the present day: Laval, Pétain and Darlan. ${ }^{25}$ Jeanne d'Arc was therefore redefined as an anti-Fascist patriotic peasant, without, of course, any reference to her campaign against the English invader.

The clandestine Communist press also circulated messages of solidarity from Britain. On 20 November 1942, Le Franc-Tireur published a message from the National Union of Railwaymen to the cheminots, then a key force in the Resistance as well as the inevitable victims of Allied bombing:

\footnotetext{
${ }^{23}$ L'Humanité clandestine, I, 477.

${ }^{24}$ William Rust, Gabriel Péri (London: Daily Worker League, 1942), 6.

${ }^{25}$ L'Humanité clandestine, II, 35-36.
} 
Nous connaissons votre sort, nous savons combien vous les supportez. Vous subissez aussi hélas les attaques des avions alliés contre vos machines utilisées par l'ennemi. (...) Gardez bon courage, camarades français, on travaille dur dans notre camp et le jour de la liberté approche. ${ }^{26}$

On 1 May 1943, the PCF distributed a message to French students from the British National Union of Students:

Nous savons que ce jour vous trouvera à vos postes, dans les Universités et dans les groupes de Francs-Tireurs, luttant à chaque instant contre l'envahisseur étranger qui a dévasté votre pays. Dès le début, les étudiants de France ralliés autour de la bannière du général de Gaulle, se sont révélés parmi les plus âpres combattants contre les occupants allemands. Nombreux sont les étudiants qui ont volontairement sacrifié leurs vies pour libérer leur patrie, tels Guy Môquet — âgé de 17 ans — et tant d'autres. (...) Etudiants nous sommes fiers de vous saluer en vous des camarades! Une immense responsabilité incombe au peuple britannique à l'heure actuelle (...) Nous ne trahirons pas la confiance que vous nous accordez, étudiants de France et d'Europe. ${ }^{27}$

The message informed the French students that, at its congress in April, the NUS had called for the immediate invasion of Western Europe, military training for students and their use in work for the war effort. British students had resolved to study throughout the summer in anticipation of the opening of a Second Front.

\footnotetext{
${ }^{26}$ APCF: 3 MI 6/142.

${ }^{27}$ APCF: 3 MI 6/143.
} 


\section{Brouillards londoniens}

On 1 December 1942, the Comintern authorized the PCF to widen its alliances and send a representative to London. Its first representative was Fernand Grenier, former deputy for Saint-Denis, who had luckily escaped from the prison of Châteaubriant in June 1941, and was charged by the Central Committee with approaching la France combattante. In January 1943, accompanied by De Gaulle's agent Gilbert Renault (Colonel Rémy), Grenier made for London with letters from the Central Committee and Charles Tillon, commander of the Francs-Tireurs et Partisans (FTP ${ }^{28}$. On his arrival, he met De Gaulle and gave a press conference. Grenier told the now legal Daily Worker: 'In France today there is neither 'Right' nor 'Left' in politics. You are either pro-Boche and pro-Vichy or anti-Boche, anti-Vichy and a whole-hearted supporter of the movement of General de Gaulle.'29

That said, despite the heroic exploits of the Resistance, Grenier was deeply concerned about anti-Gaullist intrigues in Algiers and London, with General Giraud being promoted as an alternative to la France combattante. In another interview with the Daily Worker, he claimed there were influential people who wanted to expel the Germans from France but to keep in place a certain Fascism. This reactionary influence had been shown in the long time taken to free imprisoned Communist deputies in Algeria and the slowness with which anti-Semitic legislation had been lifted there. Nevertheless, on 26 February 1943, Grenier was enthusiastic in a letter to André Marty, one of the PCF leaders in Moscow:

\footnotetext{
${ }^{28}$ Founded in early 1942, the FTP was the Communist-dominated component of the armed resistance in France.

${ }^{29}$ Daily Worker, 15 January 1943, 1.
} 
Malgré les trente mois difficiles qui viennent de s'écouler et les dures privations, je n'ai, selon le docteur, rien de cassé: beaucoup de suralimentation et ce sera... karacho! Mais quel admirable Parti nous avons et comme nos hommes se sont bien tenus devant l'ennemi! J'ai vécu neuf mois avec nos pauvres copains de Châteaubriant et je ne saurais assez dire quelle pureté il y avait en eux et quels beaux types d'hommes ils faisaient.

Grenier described to Marty his contribution to Resistance propaganda in London, starting with Radio-Londres: 'Chaque soir, 10 ou 15 millions de Français sont à l'écoute. J'ai beaucoup parlé et les Anglais me consultent assez souvent car ils me considèrent comme "très réaliste" et j'agis avec beaucoup de tact envers eux'. Grenier thus managed to obtain two important additions to the BBC broadcasts: appeals to young men targeted by the Service du Travail Obligatoire to remain on French soil at all costs, and mention of the activities of the FTP.

Elsewhere, he had published two articles in the weekly La Marseillaise, 'Mes camarades de Châteaubriant' and 'Francs-Tireurs et Partisans'. He told Marty:

Ils ont eu un retentissement considérable chez les meilleurs éléments de la France Combattante. Le Daily Worker les a repris en anglais'. Grenier was also active in popularising the French Resistance among the British: 'Outre les articles déjà parus dans le Daily Worker, j'ai donné une relation de notre travail au Comité Central du Parti britannique, publié un article dans Reynolds Views (tirage 600000 exemplaires), parlé devant les étudiants de Cambridge (les 300 présents ont chanté La Marseillaise à l'issue). ${ }^{30}$

\footnotetext{
${ }^{30}$ APCF: 3 MI 6/142.
} 
Grenier contributed to a pamphlet, France Resurgent, published by the Socialist Vanguard Group, in which the PCF's London representative presented his party as résistants de la première heure: the arrest of activists in October 1939, the student march to the Tomb of the Unknown Soldier on 11 November 1940, all confirmed by an article in the Daily Telegraph of 20 December 1940 describing the PCF as the only active patriotic and anti-German party in France. France Resurgent also showed the broad alliance of the Resistance at that time: other contributors included Albert Guigui, London delegate of the CGT, Felix Gouin, delegate of the Comité d'Action Socialiste en France, and Christian trade union leader Léon Marandat.

However, despite these positive developments, Grenier indicated to Marty the difficulties he had in communicating with the Central Committee in France: 'Je n'ai pas de liaisons directes et il faut que mes télégrammes et mes lettres passent par l'organisation de De Gaulle'. But the Communist representative seemed optimistic about the PCF's relationship with the leader of la France combattante: 'Je sais que dans un dîner récent, comme on lui demandait ce qu'il pensait des divers éléments de la résistance française, il déclara: Les communistes seuls agissent; les autres bavardent!.'31

After this letter to Marty, Grenier spoke to the French colony in Warrington, 'centre ouvrier', then in Liverpool at a big Franco-British meeting with the Syndicat des Marins français and the Labour Party. There was a lecture in Oxford on 'Paris sous la botte', a reception of the Friends of the USSR and an International Brigades Ball.

\footnotetext{
${ }^{31}$ Ibid.
} 
On 17 May 1943, in another letter to Marty, Grenier listed the documentation which he had gathered for Moscow: reports from La France combattante, documents from Vichy, as well as journals such as Combat and La France libre. However, concerning North Africa, he wrote that 'je n'ai pas encore reçu un mot écrit des camarades', although 'je sais aussi que le mouvement syndical s'est puissamment développé (en Algérie)'. News emanating from Algiers indicated the struggles for the leadership of the Resistance, especially that between generals Giraud and de Gaulle: 'de nombreuses manœuvres de tous genres s'exercent pour empêcher le Général de Gaulle de se rendre à Alger et d'y constituer le Gouvernement provisoire que réclament tous les groupes de la résistance sans exception, désormais réunis dans le Comité Central de la Résistance constitué sur le sol national'. He then commented on the quality of the broadcasts of Radio-France, based in Algiers, which did not yet represent the full diversity of the Resistance. ${ }^{32}$

However, if the Secretariat of the PCF appreciated Grenier's own radio broadcasts, notably with his advice concerning clandestine activity, the BBC in general gave grounds for concern:

Elle parle de la lutte des partisans dans les Balkans, mais jamais de la lutte en France et les Français qui sont très chatouilleux et on peut dire hypersensibles, dans la période actuelle, essayent de trouver des raisons de ce silence qui, en fait, aboutit à réduire, on ne sait pourquoi, la place de la France dans la lutte commune contre l'ennemi commun. ${ }^{33}$

\footnotetext{
${ }^{32}$ APCF: 3 MI 6/142.

${ }^{33}$ APCF: Fonds Waldeck Rochet, 307 J 154.
} 
Grenier himself was concerned about a lack of British support for the armed struggle in France. 'Will Allies be too late?', he asked the CPGB congress in July 1943, while asserting on Bastille Day in the Daily Worker that France was 'ready to leap'.34

Once his rival Giraud was finally sidelined, De Gaulle appointed Grenier as commissaire of the Comité français de la Libération nationale (CFLN) based in Algiers. Grenier was replaced in London by Waldeck Rochet, future general secretary of the PCF. Accompanied by Emile Cossoneau, Rochet flew from Marrakesh to London on 22 October 1943. He took up an office in the Commissariat de l'Intérieur, in Hill Street, and threw himself into a busy schedule which, he reported, meant he had to have tailored for him a new suit and raincoat. Rochet established relations of varying friendliness with other members of the French delegation, notably the Gaullists Emmanuel d'Astier and Georges Boris, as well as Raymond and Lucie Aubrac and the socialists of the Groupe Jean Jaurès. He was frequently in contact with the CPGB as well as the Austrian and Czech liberation committees. A brief, but retrospectively very important, encounter was with François Mitterrand: their good personal relations would help the rapprochement between socialists and communists in the $1960 \mathrm{~s}$.

As Rochet's biographer, Jean Vigreux, points out: 'l'activité de Rochet à Londres est surtout marquée par ses discours à Radio-Londres'. ${ }^{35}$ He spoke every fortnight, for five minutes, giving the PCF's mots d'ordre. His first talk, on 6 November 1943, dealt with the situation in North Africa, where he announced that a French army of 500000 men was ready to fight alongside the heroic patriots of the

\footnotetext{
${ }^{34}$ Daily Worker, 14 July 1943, 3.

${ }^{35}$ Jean Vigreux, Waldeck Rochet. Une biographie politique (Paris: La Dispute, 2000), 133.
} 
Resistance. In one of his last broadcasts, on 2 July 1944, Rochet appealed to the French peasantry not to provide food for the Occupier.

However, Resistance unity had its limits. Rochet was, rightly, convinced that his talks were censored by both the British and the Gaullists, notably Maurice Schumann. Some talks were not broadcast at all. In a letter dated 7 January 1944, Rochet described to Grenier the tensions within the Resistance in London over the emphasis of propaganda and, with that, the prosecution of the struggle. Rochet had had to fight for calls for a general strike and popular insurrection in France to be broadcast on 'Honneur et patrie': 'J'ai réfuté point par point la théorie attentiste et expliqué pourquoi il fallait appeler des grèves revendicatives actuelles, les encourager et donner des directives générales précises pour la préparation de la grève insurrectionnelle' ${ }^{36}$ Here Rochet received the crucial support of Georges Boris, though Jean-Jacques Mayoux maintained his opposition. Indeed, the reservations of Gaullists and the British authorities about 'premature' sabotage and attacks on the enemy were illustrated at the time in numerous BBC broadcasts where Schumann preached the virtues of 'un sabotage prudent and perlé'. ${ }^{37}$ Even the publication of Vercors's novel Le Silence de la mer in La Marseillaise could be seen to sanction passive resistance to the Occupier. The PCF representative also told Grenier that he had had to fight for a week to get another broadcast approved:

C'est le passage citant l'appel que notre Parti a fait dès la constitution du Front de la Liberté et de l'Indépendance et de la Renaissance française qui a provoqué les plus grosses réserves. On voudrait dans certains milieux accréditer la légende que les communistes n'ont commencé la lutte contre

\footnotetext{
36 APCF: MI 6/142.

${ }^{37}$ Quoted in John Bennett, Aragon, Londres et la France Libre (Paris: L'Harmattan, 1998), 72.
} 
l'envahisseur qu'à partir de juin 1941. J'ai réagi très vigoureusement contre cette falsification de la vérité et en fin de compte mon allocution passera, avec une semaine de retard, avec quelques retouches qui n'en changent rien au fond..$^{38}$

At the end of this missive, Rochet told Grenier: 'Je m'adapte le mieux possible à ma nouvelle situation, en espérant toutefois que le second front, qui ne saurait tarder, me délivrera des brouillards londoniens'. ${ }^{39}$

The brouillards never completely cleared. It was still difficult to maintain contact with Thorez in Moscow, Duclos in Paris and Marty in Algiers. On 19 November 1943, Rochet sent a telegram to Algiers: 'Radio-France toujours difficile à entendre en France et ici à cause puissance insuffisante et brouillage stop' ${ }^{40}$ On 3 January 1944, the Central Committee sent a concerned message to Rochet: 'Nous voyons se dessiner dans certains milieux des campagnes anticommunistes que nous sommes bien décidés à dénoncer comme autant de manoeuvres faisant le jeu de 1'hitlérisme'. ${ }^{41}$ The death in a plane crash of a PCF envoy, 'Emile', aroused Rochet's worst suspicions in a letter of 19 February 1944:

Il est un peu inquiétant de constater qu'il y a autant d'accidents. Ensuite il y a lieu de remarquer que le deuxième passager, se trouvant avec Emile, Perrier, était également un communiste (non connu en principe comme tel, mais peutêtre pas inconnu de tout le monde!). ${ }^{42}$

\footnotetext{
38 APCF: 3 MI 6/142.

${ }^{39}$ Ibid.

${ }^{40}$ Ibid.

${ }^{41}$ APCF: 3 MI 6/144.

${ }^{42}$ APCF: Fonds Waldeck Rochet, 307 J 154.
} 
Nevertheless, despite the material and political uncertainties, Rochet had been upbeat in his address to the Central Committee of the CPGB on 19 December 1943:

Nous communistes français, nous nous réjouissons des progrès qu'a réalisés sous votre direction le Parti Communiste de Grande Bretagne, car nous voyons dans ce progrès le gage le plus sûr du maintien et du renforcement de l'amitié qui lie étroitement le peuple de France et le peuple de Grande Bretagne.

The subject of his intervention was North Africa and the Party's links with the French government in Algiers. He remarked: 'Il y a eu dans l'entourage du Général de Gaulle des intrigues et des manoeuvres tendant à écarter le Parti communiste'. But he spoke confidently of a national insurrection against the Occupier. The Liberation of France would be followed by 'la suppression de l'exploitation de l'homme par l'homme'. However, 'pour aujourd'hui, ce qui doit passer au premier plan, c'est la lutte contre l'envahisseur et les traîtres'. ${ }^{43}$

On 28 February 1944, Rochet reported again on his London activities: reading and collecting mail and materials to send to Algiers; weekly meetings for radio programmes; preparing speeches and articles; filing reports to the Central Committee on North Africa; and propaganda meetings: 'le 6 février, j'ai parlé dans un grand meeting de Dundee, et, à la fin de mars, je dois aller à Glasgow où je parlerai à nouveau de la lutte patriotique du peuple de France ${ }^{44}$. On an 'eve of invasion' May Day Rally in Trafalgar Square, he told a crowd of nearly 40,000 that, except for a few, all Frenchmen were united in their desire to throw out the invaders.

\footnotetext{
43 APCF: 3 MI 6/142.

${ }^{44}$ APCF: 3 MI 6/142.
} 
Rochet's broadcasts would express the Front national's line of 'S'unir, s'armer, se battre!'. At the same time, the reliable information arriving from France led him to be more cautious in his calls for immediate insurrection. In June 1944, he advised his impatient comrades in Algiers that they must not 'précipiter l'insurrection nationale, car les maquisards ne sont pas assez armés'. ${ }^{45}$ On 15 June, Rochet expressed again his concerns: 'Les patriotes, dédaignant les conseils d'attentisme, sont passés à l'action sur tout le territoire (...) mais le drame c'est que dans bien des cas ils ont épuisé leurs munitions et manquent d'armes, alors que les Allemands attaquent sauvagement'. But Rochet had no doubts about British sympathy for the French cause: 'Je fais des réunions de temps à autre. Dimanche dernier j'ai parlé à Manchester et à Oldham, dans des meetings organisés par le Parti communiste britannique. Ça a été un succès; en ce moment les Anglais se passionnent pour la France'. ${ }^{46}$

But the situation remained very fluid and uncertain. On 10 July, Rochet still complained about BBC 'censorship' concerning the national insurrection:

Là comme ailleurs se manifeste la tendance à freiner la lutte du peuple français. On fait le silence sur certains résultats importants obtenus par les patriotes, par exemple ce qui concerne l'occupation de villes et de territoire. On ne parle pas davantage des grèves, sauf si elles se déroulent à Copenhague. $^{47}$

\footnotetext{
${ }^{45}$ Vigreux, Waldeck Rochet. Une biographie politique, 135.

${ }^{46}$ APCF: Fonds Waldeck Rochet, 307 J 154.

${ }^{47}$ Ibid.
} 
He eventually addressed a letter of protest to the Director-General. ${ }^{48}$ However, Rochet continued to make his BBC broadcasts to France. On 26 July, he made an 'appel au personnel de surveillance des prisons et des camps de concentration'. On 5 August, his theme was Brittany and the liberation of Rennes. His last broadcast came on 19 August: 'Partout l'ennemi est battu, partout il est débordé, submergé, mis en déroute, le moment est donc venu de l'achever et d'arracher la victoire avec rapidité' ${ }^{49} \mathrm{~A}$ week later, Rochet finally quit the brouillards londoniens for Normandy then a Paris in the grips of insurrection.

\section{A Fragile Friendship}

As the war entered its concluding phase, fears of betrayal had accompanied hopes of liberation. On 5 December 1943, L'Humanité announced: 'En Angleterre, le ministre socialiste de l'Intérieur, Morrison, a libéré le chef fasciste Oswald Mosley. Cette décision a soulevé de nombreuses protestations' ${ }^{50}$ On 21 January 1944, the newspaper referred to 'bruits de pourparlers secrets entre Hitler et les AngloAméricains', although it seemed reassured by a British denial of conversations with Von Ribbentrop for a separate peace: 'ces bandits se trompent s'ils pensent qu'ils pourront se sauver comme se sauva Guillaume II après la guerre de 1914--1918. Il y a des canailleries dont les peuples sont bien décidés de ne pas tolérer le renouvellement'. ${ }^{51}$

Certainly, there was intense speculation on what the PCF, the leading element in the armed Resistance of metropolitan France, would do after the Liberation.

\footnotetext{
${ }^{48}$ APCF: Fonds Waldeck Rochet, $314 \mathrm{~J} 7$.

${ }^{49}$ APCF: Fonds Waldeck Rochet, 314 J 154

${ }^{50}$ L'Humanité clandestine, tome 2, 336.

${ }^{51}$ L'Humanité clandestine, tome 2, 353.
} 
However, the struggle between Gaullists and Communists for hegemony remained subordinate to the common struggle against the Occupier and its collaborators. On 21 August, as the Parisian insurrection approached, L'Humanité declared that 'les Alliés doivent être reçus dans la capitale libérée par la levée en masse de ses fils’ and exclaimed:

Vive nos vaillants alliés anglo-soviéto-américains!

Vive la République! Vive notre grand Paris!

Vive la France libre, indépendante et démocratique! $!^{52}$

Thus la France résistante found her place in a wartime alliance now approaching its apogee.

In the Daily Worker, Sam Russell hailed 'the triumph of France': 'Now the glory of August 1944 has wiped away the shame of June 1940. Paris has risen, armed and unarmed, and the citizens, masters of their own streets, welcome their liberating allies in a city cleansed once more by the flowing blood of the oppressor ${ }^{53}$. For Russell, the victory crowned four years of struggle: 'Terror was in vain. The resistance movement grew day by day and in the lead was the French Communist Party, with its headquarters in the heart of Paris. The leaders did not flee to Bordeaux or Vichy'. 54

On 1 November 1944, Jacques Duclos, now emerged from clandestinity, granted an interview to the Daily Worker. On entering the new Party headquarters, confiscated from collaborators, Sam Russell was frisked for revolvers, grenades and daggers, due to the alleged presence of Nazi agents. Duclos told him rather

\footnotetext{
${ }^{52}$ L'Humanité clandestine, tome 2, 369.

${ }^{53}$ Daily Worker, 24 August 1944, 1.
} 
disingenuously: 'We started resisting the day the armistice was signed in 1940. We believed in armed action from the start'. Duclos 'rejected the suggestion in some quarters that present Communist support for De Gaulle may only be temporary. ${ }^{55}$ Resurgent France was, he said, the friend of Britain, the United States and the Soviet Union.

Later that month, Maurice Thorez was allowed by De Gaulle to return to France. He was now leading a party which, after the compromises of 1939-1941, enjoyed the immense prestige of le parti des fusillés. Indeed, the end of the Second World War saw the high-water mark of anti-Fascism and Communism in Europe. At the elections of 1945 , even the relatively tiny CPGB managed to send two MPs to the House of Commons, while the PCF established itself as the biggest party in France and entered a coalition government with other components of the Resistance.

In an editorial entitled 'Forward France!', the Daily Worker hailed the triumph of the PCF, but with a tinge of regret about left-wing unity which pointed back to the CPGB's own strategic and electoral frustrations: 'If the Communist proposals to the Socialists for the formation of a united party of the working class had been carried, the stage would have been set for the establishment of a Government of great strength and influence'. 56

Nevertheless, the huge success of the World Youth Conference, held in London in November 1945, seemed to show the strength of 'democratic' youth, while, later that month, the CPGB congress stood and cheered Marcel Cachin, veteran leader of the PCF. The thousand delegates joined in singing the Internationale and Marseillaise while Cachin stood waiting to speak about the PCF as the first party of France and the need for 'Big Three Unity' between Britain, the United States and the

\footnotetext{
${ }^{54}$ Ibid.

${ }^{55}$ Daily Worker, 1 November 1944, 3.
} 
USSR to be maintained. Cachin observed in his Carnets: 'Les Anglais sont contre le Bloc occidental. En Angleterre, le peuple est plus ami des Russes que des Américains. ${ }^{57}$ After the Congress, Cachin was a guest in the House of Commons, where he met the Communist MPs Willie Gallacher and Phil Piratin, but also James Maxton, the pro-Soviet Labour MP Konni Ziliacus and the anti-appeasement Tory peer Sir Robert Cecil. Cachin was then received by the 'Red' Dean of Canterbury. These were heady days. After De Gaulle's resignation, on 20 January 1946, the Communists would increase their influence in government. In November 1946, Thorez, now minister for the civil service, gave an important interview to The Times. The Communist candidate for Président du Conseil tried to reassure readers of 'the national and democratic nature of all that we French Communists are doing'. The PCF, he declared, was for a French, rather than a Russian, road to Socialism. It also wanted to merge into a broad party of the left, through fusion with Blum's Socialists and by opening ranks to Roman Catholic workers. The aim was not dictatorship of the proletariat, but 'democracy nouvelle et populaire ${ }^{, 58}$. On the post-war settlement, Thorez rejected the idea that Germany should be given a dominant economic position in Europe. Recalling that he was a boy of fourteen when his native province of Artois was subjected to the First World War, he said: 'We want the ties of friendship and alliance between Great Britain and France to be drawn more tightly, (...) I come from a province into whose soil too much British blood has flowed for me to underestimate the worth of Franco-British friendship'. ${ }^{59}$

However, this friendship would be badly shaken by the onset of the Cold War. Blum's wary Socialists were unwilling to support Thorez for the Présidence $d u$

\footnotetext{
${ }^{56}$ Daily Worker, 23 October 1945, 1.

${ }^{57}$ Marcel Cachin, Carnets 1935-1947 (Paris: CNRS Éditions, 1997), 857.

58 The Times, 18 November 1946, 3.

${ }^{59}$ Ibid..
} 
Conseil, let alone merge with the PCF, just as the Labour Party rejected the CPGB's repeated requests for affiliation. In May 1947, against the backdrop of a worsening external and internal climate, Paul Ramadier expelled the Communist ministers. By the summer of 1947, the Communists found themselves in opposition, violently denouncing economic austerity, the Marshall Plan and Anglo-American imperialism.

In May, Marcel Cachin had been back in Britain, to address 5,000 people at a rally in Manchester, where he pleaded for the continued unity of the British and French people, and made a scathing attack on American imperialism and their Tory and Gaullist allies. In private, Cachin was less positive. The material comfort of the British workers, well-paid by Ernest Bevin since the war, had, he believed, stopped the advance of Communism, and he observed: 'Les femmes ne votent pas aux réunions et sont peu communistes. Elles pensent que leur place est au foyer. Les hommes communistes le pensent aussi. (...) Depuis la guerre les communistes du Lancashire ont perdu 2000 adhérents. Si l'on n'avait pas de collecteurs pour les cotisations, les membres du PC ne paieraient pas. A Manchester on me dit: "C'est difficile, c'est impossible." Passivité ${ }^{60}$. The first-past-the post electoral system was also a formidable obstacle.

Despite the collapse of 'Big Three Unity', there remained grounds for optimism. In their report on the eleventh congress of the PCF, in June 1947, Pollitt and Dutt wrote:

We left Strasbourg feeling we had been permitted to take part in an extrardinaryly [sic] important Party Congress, from which we learned a great deal, and whose results will quickly manifest themselves throughout France,

\footnotetext{
${ }^{60}$ Cachin, Carnets 1935-1947, 1114-115.
} 
and will undoubtedly increase the pressure of the French people for the Communist Party again taking part in the work of the French Government. ${ }^{61}$

In November 1948, with France in the grip of a wave of strikes as well as facing anti-colonial insurrection, Marcel Cachin wrote to R. Palme Dutt: 'Things progress rapidly here. Our reaction is rampant, resorting to blind violence and provocation: ultimate cards of foundering castes and regimes' ${ }^{62}$ However, subsequent years would show that, with the division of the world into 'two camps', French and British Communists were driven into a ghetto that would mean slow decline for the PCF and electoral oblivion for the CPGB.

University of St Andrews

${ }^{61}$ Archives of the Communist Party of Great Britain (Manchester): CP /CENT/INT/45 (hereafter APCGB).

${ }^{62}$ ACPGB: CP/IND/Dutt/06/04. 